\title{
Early Childhood and Lockdown: The Challenge of Building a Virtual Mutual Support Network between Children, Families and School for Sustainable Education and Increasing Their Well-Being
}

\author{
Ana Belén Cano-Hila ${ }^{1, *(\mathbb{D})}$ and Rafel Argemí-Baldich ${ }^{2}$ (D) \\ 1 Department of Sociology, Faculty of Economics and Business, University of Barcelona, \\ Avinguda Diagonal 690, 08034 Barcelona, Spain \\ 2 Department of Methods of Research and Diagnosis in Education, Faculty of Education, \\ University of Barcelona, Passeig de la Vall d'Hebron 171, 08035 Barcelona, Spain; rargemba7@alumnes.ub.edu \\ * Correspondence: anabelencano@ub.edu
}

\section{check for}

updates

Citation: Cano-Hila, A.B.; Argemí-Baldich, R. Early Childhood and Lockdown: The Challenge of Building a Virtual Mutual Support Network between Children, Families and School for Sustainable Education and Increasing Their Well-Being. Sustainability 2021, 13, 3654.

https://doi.org/10.3390/su13073654

Academic Editor: José Antonio Marín-Marín

Received: 5 February 2021

Accepted: 22 March 2021

Published: 25 March 2021

Publisher's Note: MDPI stays neutral with regard to jurisdictional claims in published maps and institutional affiliations.

Copyright: (c) 2021 by the authors. Licensee MDPI, Basel, Switzerland. This article is an open access article distributed under the terms and conditions of the Creative Commons Attribution (CC BY) license (https:/ / creativecommons.org/licenses/by/ $4.0 /)$.
Abstract: The COVID-19 pandemic is questioning the achievement of main challenges we face as a society, for instance, to ensure a free, equitable, and good quality compulsory education for all children or to reduce social inequality. During the spring lockdown, particularly in Spain, schools were closed for six months and a process of virtualization of teaching was total; that context generated important educational challenges. This paper presents and analyses forms of digital reciprocity and solidarity among pre-primary education children, families, and teachers, by presenting a case study of the parents' WhatsApp class groups and a collaborative YouTube channel. The procedure developed was netnography and the data analysis followed the model of grounded theory. Both digital spaces created by parents have become a network of mutual support. It has had multiple positive impacts: (i) providing and receiving social support; (ii) generating dynamics of reciprocity and empowerment; and (iii) activating values that generate a sense of community (feeling of belonging, trust, etc.). The case study shows how virtual networks increase the subjective well-being of participants in a difficult context and also invites reflection about the key role of cultural capital of the parents as a key element in the conditions of educability of children, especially in e-learning of pre-primary education.

Keywords: early childhood; lockdown; e-learning; mutual support; reciprocity; solidarity; educational community; well-being; sustainable education

\section{Introduction}

Before 11 March 2020, when the World Health Organization announced the COVID-19 pandemic [1], the world was already facing a learning crisis and was quite far from meeting the UN's Sustainable Development 2030 goals that comprise all nations within the aim of ensuring that "all girls and boys complete primary and secondary education, which should be free, equitable, and of good quality" [2]. This situation also comprises the achievement of another of the main challenges we face as a society, which is to reduce poverty and social inequality as they significantly hinder the construction of a model of society that is fair, democratic, inclusive, and sustainable.

The arrival of the coronavirus in our lives has evidenced and intensified the weaknesses of our system in its multiple dimensions: economic, political, social, family, and educational. Particularly, in the educational context, this pandemic represents a threat to the advancement of education worldwide, impacting essentially on two issues: First, the global closure of schools at all levels where more than 1.5 billion pupils in 197 countries had to switch to home schooling [3,4]; and, second, the economic recession generated by the control measures of the pandemic. On the one hand, school closures lead to learning 
losses, increased early school leaving and school failure, and greater inequality [5-7]; on the other hand, the economic crisis intensifies the social vulnerability due to reduced labor activity, unemployment, lack of social benefits, and so on. Agencies such as the UN, OECD, and the World Bank [8] predict that these two impacts will, together, have a long-term cost on human capital and well-being. It is feared that the impact of COVID-19 in education could waste great human potential and reverse decades of progress. Against this backdrop, the UN Secretary-General said "As the world faces unsustainable levels of inequality, we need education - the great equalizer-more than ever. We must take bold steps now to build quality, inclusive and resilient education systems fit for the future" [9].

In Spain, schools are recommended to close on 12 March 2020 [10], lasting for six months. This total closure begins and coincides with the harsh containment measures for the general population, which began on 14 March with the publication of Royal Decree $463 / 2020$ [11], and especially for children [5-10]. Since, at that time, children were believed to be important transmitters of the virus [12-14], much pressure was exerted to prevent their presence in public spaces. In fact, they spent 45 days totally confined, unable to go outside, until, with the publication of Order SND/370/2020 of 25 April 2020 [15], when the relief measures were approved, they were allowed to go out for one hour a day, with an adult and within a radius of one kilometer from home, although, access to playgrounds was still forbidden. It was not until the start of the 2020-2021 school year that early childhood education, primary education, and compulsory secondary education returned to the classroom, while post-compulsory education and higher education remained in blended or virtual education, depending on the evolution of the health situation.

Since the beginning of the pandemic, states have been committed to protecting education, closing educational centers and opting for distance learning in its multiple forms: digital platforms, radio and television programs, pre-recorded videos, etc. $[4,16]$, with virtualized education being the majority in upper-middle income countries [17], as is the case in Spain, where each center has been left free to choose the mode of virtualization (synchronous and asynchronous), the timing (full-time, part-time, etc.), and the type of platform to be used [18]. However, the work of Thorell et al. [3] shows that in Europe, in the spring of 2020, schools had serious difficulties in adapting to online learning, that teaching was of low quality, that little support was provided by schools, and that homeschooling had negative effects on both children and adults.

The various published studies mostly point to the fact that the process of virtualization of education, which had begun slowly earlier, has accelerated during the pandemic $[19,20]$. This abrupt process has some light and many shadows. Among the potentialities of this virtualization, the multiple opportunities offered by virtual platforms to maintain contact between peers [21] stand out, which helps to maintain or increase subjective well-being among students in the face of isolation at home, as well as to allow for further development of school tasks. On the other hand, a number of limitations have been pointed out: at first, an important digital divide between students was revealed, which in most cases was attempted to be solved by providing computer equipment and internet connectivity [22,23], however, it became evident that the availability of technical means did not ensure distance education [17,24], and families, apart from teleworking [25] and managing their children at home, became key players in the implementation of virtualization of education, either by supporting, guiding, or accompanying their children throughout the process [3,18,25-29]. The fundamental importance of family involvement in their children's education highlights and increases educational inequalities among students [3,16,17,26,30-32], including parents' lack of technical expertise $[16,26,30,32]$, lack of training to understand the activities $[17,24,26,27,31]$, or time spent with their children [18,25,32-34], and in the case of Spain, between 10 and 14\% of students did not connect to e-learning [31]. In short, having an e-resourceful family, with a higher level of education, with one of the parents trained to help with homework, substantially improves the chances of successfully pursuing online education [27,31].

Much of the published literature on the impact of the pandemic on education focuses on the stages of compulsory education, post-compulsory education, and, most especially, 
higher education. In only $60 \%$ of countries was distance education developed for the early childhood education stage [17], although $69 \%$ of students were unable to participate for various reasons [17], and in the case of the USA, nearly $40 \%$ of children did not participate regularly in virtualized education [35]. At this educational stage, and given the difficulty of virtualization of education due to the fact that contact, experimentation, and interaction between peers is fundamental $[25,32,34]$, the family again becomes indispensable in order to develop the educational process $[17,24,25,29,32,34]$, either by helping children to concentrate $[25,29,33]$ or by accompanying them in activities $[24,29,34]$, which again translates into an increase in educational inequalities [36]. Likewise, the virtualization of teaching in young children has led to a burnout caused by the excessive use of virtual synchronous forms of communication [37], known as Zoom fatigue [38].

In short, the scientific evidence published to date has focused especially on the limitations of the forced virtualization of teaching, particularly in the stages of compulsory education and higher education, with only residual work on early childhood education. Furthermore, there has been little exploration of the discourses of children and their families on home schooling in order to understand how they have experienced this extraordinary situation. Likewise, no attention has been paid to the responses and adjustments made by the educational community, fundamentally the students and families, to maintain education at home in the impasse of time when schools did not offer an institutionalized response, at a time when the home became the center of work, the gymnasium, the place of leisure, and practically the only space in which to develop daily life.

Considering these gaps, the main objectives of this article are threefold: on the one hand, to analyze the narratives of children and their families about home education in order to understand what emotions, activities, and situations they have experienced in the context of the total confinement of spring 2020. On the other hand, to study how pupils in the first year of the second cycle of infant education, as well as their families, have organized themselves to develop creative and innovative responses in order to carry out education at home, at a time when school had not yet been formally organized and had to be made compatible with teleworking and confined family leisure time. Finally, to identify and explore the impact and effects of these communication and interaction networks created by pupils and families, especially in terms of subjective well-being and social support. In order to develop these objectives, this article presents and analyzes a case study: a first-year class in the second cycle of preschool, called Cargols, in a statesubsidized school in Barcelona. This case study is based on two documentary sources: a WhatsApp parent group of the class (named Cargols, in English snails) and a private collaborative YouTube channel Cargol Treu Banyes (Snail takes out your antenna). This name corresponds to the name of a traditional Catalan children's song. In our case, it is the metaphor of the children shut up at home, just as the snail is shut up in its shell, and the antennae of the snail that connects them with their classmates.) These sources were created by a group of mothers and fathers on the same day that schools were closing in Spain. In a spontaneous and self-organized way, they decided to dynamize the class WhatsApp group, as well as to create a private and collaborative YouTube channel Cargol Treu Banyes, with the main aim of breaking the social isolation of their children and also of the families during the quarantine, thus improving their mental and emotional health. Subsequently, these networks also become a channel of communication and collaboration with the school and the tutor.

The article is organized according to the following structure: firstly, it presents the main effects of the total confinement experienced in Spain during spring 2020 on young children, as well as the difficulties it represented for infant education. Secondly, the methodological considerations are presented. Thirdly, the main results achieved are shown and explained. Next, we move on to the discussion, and finally, the conclusions are presented to summarize the most relevant contributions of this article. 


\section{Early Childhood and Confinement}

2.1. Isolation and Demotivation: Consequences for Young Children of the Spring 2020 Confinement and Total Closure of Schools

According to different studies [39,40], children accepted and assumed the measure of confinement as necessary, appealing to the fact that it was an individual and collective protection strategy. A very repeated positioning by children has been to "be nervous, overwhelmed and scared by the possibility of infecting their grandparents" [39] (p. 13).

Despite this responsible acceptance of the measure, as confinement became longer, especially for children, many voices of pediatric and psychological professionals, as well as various works $[5,10,40,41]$, pointed out the important impact that confinement has on mental health and child development. They explained that despite the lack of scientific evidence on how confinement can affect them [10], because it is an unusual situation, there are known factors that can increase the risk of stress, anxiety, and frustration. It was also pointed out how home confinement was affecting all the key areas of early childhood neurodevelopment (up to age 7): from movement, to social relationships, to play and learning.

Various studies $[42,43]$ argue that confinement can lead to problems related to insomnia, irritability, and exhaustion, among other mental health problems. Particularly in early childhood, some signs of these disorders have resulted in nervous tics, very intense tantrums, nightmares, and loss of sphincter control. Significant associations have also been identified between confinement and negative emotions such as fear, sadness, nervousness, or even feelings of guilt.

$86 \%$ of health professionals say that confinement has had a negative impact on children's health [10], $85.7 \%$ of parents say that children have experienced changes in their emotional and behavioral state [44]; and a large number say that children have spent more time in front of screens, have slept more, and have been less physically active $[5,39,43]$.

In short, subjective well-being, understood as people's overall assessment of their lives and emotional experiences $[45,46]$, as well as the quality of life of the child population, has been severely damaged by spring lockdown.

\subsection{Effects of COVID-19 on Children's Education: "Checkmate" to the Main Lever for Mitigating Social Inequalities and Enhancing Equity}

Early childhood education is considered as a key stage in laying of the foundations for the personality and development of the adults of tomorrow. It is also fundamental as it improves the well-being of children, encourages physical and emotional development, promotes gender equality, and has a great impact on equity and the reduction of inequality and child poverty [47]. Therefore, child education fulfils two main purposes: to lay the foundations for the development of reflective, critical, active, and competent citizens, as well as to facilitate family reconciliation with work, which in turn directly impacts on issues of gender inequality and inequality in employment.

Containment measures in response to the COVID-19 crisis disrupted conventional education with the nationwide closure of schools. In response, the early childhood education sector gave priority to the personal and family well-being of pupils and the accompaniment of families [48], attempted to adjust the meaning of education, characterized by experimentation, attachment, and physical contact, to the new reality [29,34] by starting important initiatives to maintain continuity of learning during this period based on proposals, suggestions, and recommendations for non-assessable weekly voluntary activities. [48]. However, early childhood education students have had difficulties in following the activities proposed by schools [48], either because of their limited digital skills, due to their young age, or because of the digital divide [16,27], generating processes of demotivation, loss of routines and schedules [17,29,49], and possible school drop-out [50]. This situation also leads to a reduction in their capacity for autonomy and self-regulation in children's learning $[24,26,29,51]$, and the intensification of pupils' dependence on family resources, both material (electronic devices) and immaterial, relating to the cultural and educational 
capital of families and their willingness to dedicate time to accompany and guide them in distance education via the internet. On the other hand, teachers show a significant feeling of being "overwhelmed", due to the intensification of communication with families [50], the increase in workload [52], or the constant changes in measures adopted by the administration [50], in addition to the fact that they have to deal with a growing number of problems [51], including the lack of training for teachers to adapt to new pedagogical concepts and ways of teaching $[27,29]$.

In short, infant education has been one of the stages most affected by the closure of the classroom-based modality, because distance education, which also presents many limitations at the other levels, has proved to be particularly ineffective in responding to the needs of families and children of these ages [3]; despite the efforts that have been made [27], there have also been complaints from families who felt that not enough work has been done during this period [50]. Social learning [53-56] developed through social interaction, such as socialization, coexistence, and learning among equals, understood as key teaching-learning processes for the development of empathy, mutual trust, reciprocity, and solidarity, are objectives that are difficult to achieve without experiential and physical interaction among teachers and classmates.

Considering this panorama, various works $[27,43]$ raised up two main reflections, which are translated as the challenges in educational policy in the short and medium term: on the one hand, the inequality of the school effect on learning, and how its virtualization in a context of the digital divide gives too much importance to the cultural and economic capital of the family in the teaching-learning processes, thus questioning the equalizing and equitable role of education, and in particular of infant education. On the other hand, the relevance of the school as an institution that watches over and cares for the integrity of children [48], in the face of some critical voices regarding the gap it represents within the society, the irrelevance of teachers, and the virtues of self-learning processes.

\section{Materials and Methods}

\subsection{Method}

To respond to the objectives proposed in this article, a qualitative text analysis was carried out [57] (p. 341) which inductively examined how a group of parents from an early childhood education class created the WhatsApp and the private and collaborative YouTube channel "Cargol Treu Banyes", and in particular, the impacts of that experience on early childhood education students, families, and schools in terms of mutual support and social interaction at a time of total confinement.

The need to address the gap in the literature described above, and consistent with our aims, meant that grounded theory was the chosen methodological choice. Grounded theory is defined as the discovery of theory from systematically obtained data in social research, in which the researcher is fully immersed in the information to be analyzed [58,59]. This method of research is identified as preferable for addressing and understanding the ever-changing reality of psychosocial processes and giving voice to invisible groups [60], such as early childhood in this case.

The use of grounded theory as a methodology can help to reveal some insights into the views of children and their families on how they have experienced quarantine and school closure, what responses they have articulated to the need to continue home schooling, preserve their subjective well-being, and support themselves in a context of social isolation.

\subsection{Participants}

Participants were 25 pupils, aged 3 and 4, who were in the first year of preschool education during the 2019-2020 academic year, and their families, from a subsidized school in the Bonanova neighborhood (Sarrià-Sant Gervasi district) in Barcelona. Non-probability sampling was chosen for accessibility and convenience. Of the 25 families, 22 mothers and 15 fathers took part in these virtual networks and channels. Out of a total of 2447 interventions or messages registered between 13 March and 21 June 2020, 88.47\% were 
made by women and $11.53 \%$ by men, and 530 videos were made by children, recorded between 13 March and 21 June 2020.

The participants are the students of the pre-primary education and their parents. Most of the members of the parents' group are middle and upper-middle class, have higher education (university or advanced vocational training), and in all households at least one member has university education. The jobs they mostly perform are in the fields of health, audiovisual, education, or accounting.

\subsection{Techniques and Procedures for Collecting Information}

Considering the situation of confinement and state of alarm that we were experiencing, the procedure used to develop the research was essentially netnography [61]. This is a "specific set of ethnographic practices, data analysis, ethics and related representation, carried out using the social and cultural data that people freely share through the internet" [61] (p. 1). In netnography, the techniques of traditional ethnography are adapted to the study of communities that have emerged through online formats [58], and their bases lie in the value of understanding what happens within the online format itself, from a cultural perspective [61-63].

Consistent with this procedure and with the social and health circumstances we were experiencing, the online channels used were the WhatsApp group of the "Snail" class and the YouTube channel "Cargol Treu Banyes".

Following the grounded theory model, based on a coding process divided into three moments [58,59], the data analysis, developed with the qualitative analysis software NVivo 12, was organized according to the following phases:

- In a first phase, the conversations in the WhatsApp group were divided and coded into concepts, being from a total of 2447 interventions, as well as the 530 videos uploaded to the YouTube channel, according to a descriptive taxonomy, the result of a first reading of the data. The codings were inductive and focused on identifying the elements, people, relationships, practices, actions, and emotions present in the messages and videos.

- In a second phase, the descriptive codings were regrouped into interpretative categories, based on the re-reading, revision, and constant comparison of the data.

- In the third phase, the categories were integrated to reduce the number of concepts and thus delimit the theory. The categories and the data were reviewed and subjected to constant comparative analysis until the maximum level of saturation of the data was reached. In this way, the categories constructed explain and make sense of the data and their relationships, and explain the patterns or objects of study.

From the analysis, four central categories were detected and constructed: (1) relationships between children and their class group; (2) relationships between families; (3) relationships between children, families, and school; and (4) impacts of these virtual relationships on each of the participating actors, which articulate the presentation of the results and their subsequent discussion.

\section{Results}

\subsection{Relations between Children and their Class Group: Autonomy and Empowerment Versus Isolation and Demotivation}

Analysis of the content of the interventions and participation of the children and their families in both the WhatsApp group and YouTube channel showed how the children provide support to each other on a semi-autonomous basis. The parents record and share their videos, audio, or photographs, but on many occasions, children are the protagonists of their own messages, without the intermediation or reinterpretation of adults.

Both channels are presented as a way of breaking the social isolation that comes within being confined at the home, both in relation to the peer group and to the group's teacher. 
The main dimensions on which such support impacts are as follows: (i) activation of the motivation for activities and learning, (ii) feeling of belonging to the class group and the school, (iii) positive reinforcement, and (iv) emotional support.

\subsubsection{Activating Motivation for Activities and Learning}

At first, when the school did not yet formally articulate distance learning, the students established a dynamic of "challenges", motivating themselves to carry out a specific activity, to record themselves, to share it among the group, and to name the next challenge or person who should share their task. This participative dynamic, and the observation of the outputs of these challenges, activated children and encouraged their participation. Thus, for instance, a girl showed her classmates how to make the challenge of Santa's beard with flour, and named another classmate to make the challenge "Hello snails, after days ... here is Santa's challenge ... 웅요 I pass the challenge to ... [name child]" (AL4_09/04/20_12:18:18); and then the named classmate accepts and makes the challenge "Good families, we have also accepted the challenge you proposed! Have a good holiday

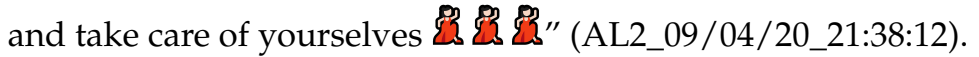

Along the same lines, another student uploaded a video to the YouTube channel motivating his classmates about the use of the mask and proposing that they show themselves with it: "I wear my mask as if I were a doctor, it has pictures on it and I go on the metro, what about you? $\odot \odot \bigcirc$ Do you want to wear it?" (AL6_28/05/20_17:26:12); and another proposed that they hang a photo on the WhatsApp channel: "Snails! A fun proposal ... look for a photo of children and try to make it the same! It was fun!" (AL12_10/04/20_13:44:16).

\subsubsection{Sense of Belonging to the Class Group and the School}

"I'm happy to be a snail, the best class in the world ... 대유 (AL7_10/04/20_12:06:31), or "I love you snails, and that's why I made a drawing of you, I miss you a lot" (AL20_14/04/20_16:09: 05), are some of the recurrent comments in many of the speeches made by children that emphasize the link with the school, the class group and the classmates, even though it was a group formed only 6 months before the beginning of the pandemic; something interesting to take into account, considering the age of the students.

It also enhanced the bond, ties, and trust between students. An example of this is AL5's proposal: "I propose a game that we have made with mummy, you have to know which of you is talking" (AL5_23/03/20_17:15:56), as well as AL9's comment "What snails ... you are so cool" (AL9_09/04/20_11:37:57).

\subsubsection{Positive Reinforcement}

The group, both pupils and families, are responsible for providing constant positive reinforcement with regard to the activities and tasks carried out by the children, giving them confidence both individually and as a group. In this sense, the three stories are an example of positive reinforcement: "Well, that volcano $\&$ is spectacular! It's a perfect metaphor for these moments $88 \odot \Theta \odot$ " (AL3_09/04/20_9:33:57); or "Your drawing is impressive, [child's name]! Good job! The teacher will be very happy to see it" (AL18_09/04/20_11:21:24); and finally, "My goodness, how many things you, snails, dads, mums, brothers and sisters do! 80 " (F21_09/04/20_19:14:51).

It is remarkable how this positive reinforcement-especially among peers-activates motivation and increases participation and performance in both school and leisure activities. This is evidenced by messages such as the following: "You have made some very beautiful cats! We still haven't had time to finish it, let's see if we can do it these days and show it to you!" (AL13_10/03/20_10:34:10). 


\subsubsection{Emotional Support}

Social support teaches us that we are part of a society, of a group where people help and care about us, and that all of this facilitates our well-being. Within social support there is emotional support, which is based on showing affection, empathy, active listening, and acceptance, among other actions. This is how both testimonies express it. For instance, in relation to the loneliness of confinement and the strength that comes from being able to communicate with each other, messages such as: "These snails are the cane! We will also miss you. Shared feelings occupy us all the time, but they also give us a lot of energy" (F4_09/04/20_12:13:12); and, in relation to the importance of watching videos in the face of social isolation, an example might be: "I miss you very much, snails and I love watching your videos" (AL19_09/04/20_13:31:42).

Emotional support is considered one of the main sources of well-being, especially in times of difficulty or crisis. At these times, it is important to remember that we are not alone, and that physical distance does not imply emotional distance or lack of affection. In this line, some participants commented, in regard to the importance for her child to get birthday greeting drawings made by their classmates, in both forms by sent photographs through the WhatsApp or by explanatory videos on the YouTube channel: "Thank you families! You are fantastic! She has been very happy with your videos and drawings!" (F19_12/04/20_17:11:35); and "When he sees the snails! His eyes shine. Thank you all for this company $\bigcirc$ () ()" (F11_17/03/20_20:33:38).

\subsection{Relationships between Families: Understanding and Exchange to Cope with Disruption 4.2.1. Information Support: Exchange of Educational and Entertainment Resources}

When families have to manage their children's family time, school time, and leisure time, there is a clear need for how to occupy all that time possible, which, until the pandemic, has been done by other agents such as school, extra-curricular activities, and the extended family, among others. From this need is where the intense exchange and share of resources such as didactic and cultural materials, as well as leisure and entertainment activities, arise. In this sense, for instance, one mother, who works in the school, pointed out: "Yesterday with my school teacher we were saying that maybe it would be good for us to make a daytime schedule, $x$ structure it. These are ideas, otherwise the day is much longer 의" (F21_13/03/20_9:09:44); another one thanked the proposal: "Great, thanks" (F22_13/03/20_9:26:22).

Another example is the family proposal for creating a YouTube channel to encourage participation and the exchange of ideas and activities to entertain children while families are working or doing household chores.

"We have thought that by having to stay so many days at home locked up we can go away challenging ourselves among our classmates. That's why we've created a Gmail account and started a YouTube channel to have other channels besides the WhatsApp group in class. For the moment we have sent a proposal. We hope you like it and that you will participate" (F23_13/03/20_11:51:07).

In response, someone else added: "We will do it soon (today we were able to pull [girl's name] on our own initiative, without having to rack our brains too much, but

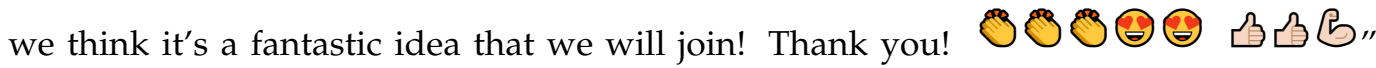
(F10_13/03/20_20:31:03). Another family proposed: “Another idea I can think of to keep them entertained for a while we work or cook is to put the videos on the YouTube channel in playlist mode, and we can ask them to close their eyes and they have to recognize their

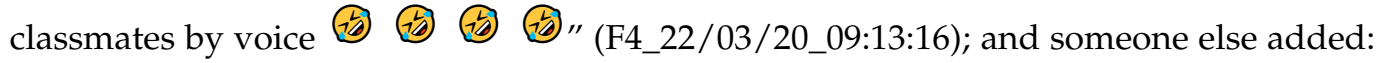
"There is also a girl who has a channel called confined stories https:/ / www.youtube.com/ watch? $\mathrm{v}=\mathrm{DhhThzuN1 \textrm {AM }}$, and she offers storytelling and songs every day from 10 to 11

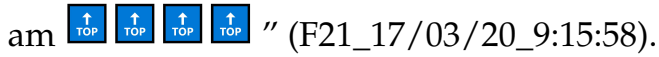


Other mothers and fathers, taking advantage of the educational resources, concerts, plays, etc. that emerged during the time of strict confinement, participated in both the WhatsApp and YouTube channels, making these resources and activities known to the children. In consequence, for instance, someone proposed a play: "Good morning to everyone! Willy is a friend and actor, and this is his recent work as a home helper. 凸凸凸” (F18_18/03/20_9:51:29); “Families! tomorrow the singer Damaris Gelabert will give a free concert for all children! I'll pass you the link https://youtu.be/m8 IUrWex0Ts" (F24_18/03/20_10:42:16); "Families! we have seen that the Abacus shop has opened its online shop and they take orders home ... in case you might be interested" (F4_21/03/20_18:52:43).

Among other topics, it was interesting to see that there is also a mutual support and exchange of knowledge and learning linked to the use of new technologies and social networks. To highlight this argument, there was a message in regard to the operation of YouTube: "Hello! A doubt, how can I access the YouTube account to upload videos? Sorry we haven't tried that until now! B" (F14_10/04/20_13:34:00); which had been replied to by another family: "I'm sharing a video with you on how to post the videos on Snails' YouTube" (F23_10/04/20_13:34:10). Another example would be the following message: "Good morning snails! Here we are improving the technique, a week ago we had never

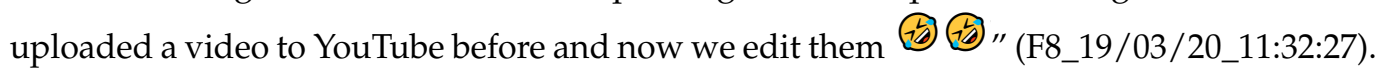

\subsubsection{Emotional Support: Empathy, Trust, Solidarity}

The data analyzed shows that one of the main reasons why families are active in this virtual support network is because it provides them emotional support, articulated through empathy, trust, solidarity, reciprocity, and the positive reinforcement of their attitude and behavior in regard to parenting during a complex and unprecedented context. This is expressed in many testimonies, such as a conversation between families about their children:

- ' 'Tomorrow I'll have my baby back, so I hope I can do some of the little things you've

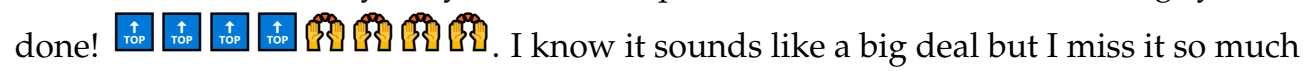
... $\odot \odot \odot . "$ (F6_09/04/20_11:38:26).

- "It's not a cliché!! and so much so that they miss each other!" (F2_09/04/20_11:56:43).

- "How right you are ... it's exhausting and more so these weeks ... but it's so worth it ... Cheer up, we're doing our best ... cheer up, cheer up ... B $b$ b (F28_09/04/20_13:13:23).

Another example, also based on a conversation between families, emphasizes the implementation of school activities proposed by the school:

- $\quad$ "Super artists all and all! My son doesn't really want to do the school activities, so so far we haven't done any (ㅇ) ." (F19_17/05/20_11:53:36).

- "Same for [child's name] 응 ." (F17_17/05/20_11:54:28).

- "We are the same 눈? (F22_17/05/20_13:34:15).

- "It's OK ... there are a lot of days and things to do ... they are very small :) ." (F4_17/05/20_18:15:59).

- "They're all superpimps, and it's not always easy to get them on, so thanks a lot, snails! No one should be overwhelmed! This is how it goes and there are times when it does and others when it doesn't . (F8_23/05/20_17:31:47). 


\subsection{Relations between Students-Family-School: Reference, Linkage, and Follow-Up}

\subsubsection{Information and Interaction between Students-Families and Tutor}

The virtual mutual support network also managed to connect students and families with the tutor and the school. At first, when the school had not yet developed distance learning tools or activities, the YouTube channel was shared with the teacher, thus becoming an informal channel of communication and interaction between students-teacher and families-teacher. This is how a testimony was given when the teacher also joined the YouTube channel: "The [name teacher] has also accepted the challenge! And here she leaves us the sample..." "(F23_09/04/20_18:17:14).

\subsubsection{Guardianship as a Reference and Reinforcement of Parental Authority}

By participating in the initiatives proposed by families, the teacher reinforced her authority and reference among the students and strengthened the authority of the many weeks of school at home. This is reflected, for example, in the following comment: "Snails, I am very happy with how hard working you are, keep it up, and remember that you have to listen to the parents ... and for the parents to say keep it up, you are doing very well" (MT_29/04/20_10:15:56).

\subsubsection{Communication, Bonding, and Trust}

The WhatsApp group and YouTube channel strengthened not only communication but also trust and bonding between these groups. Thus, one family reflected on the virtual activities proposed by the school:

"I share a concern with you, socialization is very important at this age: why do children need it like the air they breathe, and why do they grow and learn emotionally by socializing? I am very worried (in fact, I don't care if he doesn't learn to write his name now) that he won't be able to socialize and share experiences with his classmates" (F22_23/05/20_10:47:20).

Other testimonies established a conversation about the impressions of the video conferences held between students and teachers:

- "Yes! I'm sure there will be more! My child is super happy to see them, although he says he has spoken little" (F15_21/05/20_12:11:25).

- "Yes, what they cannot say is a pity, basically because we see what they want and need: to communicate and to talk. Perhaps we could also transfer this need to the teacher. The children want to talk to her and sometimes the video conference makes it difficult, perhaps better with the mobile phone ... " (F4_21/05/20_12:15:42).

\subsubsection{Monitoring, Assessment, and Evaluation of Learning}

Later, when the school structured and articulated virtual teaching, the teachers of early childhood education continued to use this space of virtual meeting for two main purposes: on the one hand, as a means of interaction with the students (stories, dances, songs) and, on the other hand, as a repository of evidence of the activities carried out by children, as a means of monitoring, assessment, and evaluation:

"Families, I would like to tell you that in order to make the report for this term I will base it on all the evidence that you have posted on the YouTube channel and also on those that you have sent me by post. This year is exceptional and we are all doing quite well together" (MT_02/06/20_11:32:26).

\section{Discussion}

The results show that, in an unprecedented context of drastic social isolation, school closure for six months and an incipient virtualization of teaching, with the limitations this implies for early childhood education [49-51], the parents of the snail class and pupils selforganized and developed a creative response to break the social isolation that quarantine entailed, to continue with home schooling and to facilitate the reconciliation of care and telework, through the dynamization of the WhatsApp group of the families, as well as the 
creation of a YouTube channel Cargol Treu Banyes. These channels become a network of mutual support between children, families, and, subsequently, the school. This network has had multiple positive impacts on the participants, especially in terms of increasing their subjective well-being in a situation of confinement and pandemics. These positive impacts are as follows:

First, social support, understood as the set of emotional, material, information, or companionship contributions that the person perceives or receives from different members of his/her social network [64], is one of the most important resources that people have to adapt to their environment [65] and contribute to improve their well-being [45,66]. The importance of social support lies in its effects on people, especially in terms of well-being and specifically in variables such as self-esteem [67], mood, feeling of belonging to the group [68], and the increase in self-efficacy and belief in the ability to control aspects of the environment [69]. The observed results of the Cargol Treu Banyes' experience include a large part of these elements of social support explained and validated in a broad way within the literature on this concept, and it is remarkable how the virtual support network offers a space for meeting, communication, interaction, and socialization, which, in turn, besides the virtuality, minimizes the isolation and social distancing that confinement implies [28,70], and, in consequence, also helps to mitigate its harmful effects in terms of mental and emotional health and school learning, in concordance with other studies [5,39,43], to mention: apathy, inactivity, and demotivation, among others. In particular, children constructed a way of playing and learning among themselves through the shared videos and photos, which increased their motivation in respect to the proposed activities and their participation in the network, thus reinforcing the conclusions of work such as $[65,71]$.

Second, this digital space conformed by both the WhatsApp Group and the YouTube channel had a positive influence among the two key components of subjective well-being, the affective and the cognitive [45] of all its participants, insofar as they feel accompanied and at the same time accompanied. By this dynamic, a type of relationship is established, based on a bond that Polanyi [55] calls reciprocity and, therefore, empowers all the people involved (in the activity), by converting them into receivers and senders of affection, company, support, and help at the same time [72].

Third, the Cargol Treu Banyes platform directly impacts among elements that activate social capital; this means a sort of collaboration between actors, by elements such as affection, mutual trust, social relations, norms [54], reciprocity, exchange, and solidarity [55]. Studies on social capital-from a relational perspective-point out how the activation of these values or assets promotes the construction of community, of living together-as Tönnies [73] argued-developing lasting social links, which are emotionally charged, and which mostly provide social support and other protective resources for emotional distress and social vulnerability. These characteristics are validated by works such as Santoveña-Casal \& Pérez [74], who reaffirm the importance of social and collaborative models in sustainable education, since both types of models promote a positive learning experience. They also reinforce the relationships between students, the feeling of belonging to a community with shared interests, and the feelings of belonging and cohesion.

Fourth, and finally, the analysis of this experience demonstrates the key role that family plays in education [3,18,25-29], especially during infant ages [17,24,25,29,32,34], highlighting the role played by the digital skills [30,32] and cultural and educational capital of the parents $[18,27,31]$ as a key element in the conditions of educability of children, especially at this time of life which, in turn, invites and opens an in-depth debate in relation to the issue of social inequalities, as well as poverty and its impact on education $[7,27,31$, $43,75]$.

\section{Conclusions}

The personal participation and analysis of this experience, reflected in the present netnography, allowed us to reflect: 
On the one hand, on how the spontaneous participation of a group of mothers and fathers, in a context of confinement and school closure, builds a network of mutual support for children, families, and schools. This network manages to mobilize the main assets that make up social capital, such as trust, empathy, affection, reciprocity, solidarity, or exchange, giving rise to a virtual community. This community provides social support to its members, which translates into an improvement in their emotional well-being, their development of learning, and their capacity for empowerment [71]. At the same time, and because early childhood education also focuses mainly on the personal and family well-being of pupils, and the accompaniment of families, this virtual community complements distance education for children, which has a very difficult time fulfilling its socially assigned tasks, objectives, and approaches, and strengthens the link between students, families, and school.

On the other hand, this case of study invites us to place more decisively at the center of the debate the influence of the cultural and educational capital of parents among the education of children, particularly in a unique virtualized, distance-education environment. In this sense, we consider it important to qualify the criticism that has been made about schools that describe them as obsolete institutions, in need of continuous adaptation and innovation processes, in order to reinforce the role of the school as an institution of social protection for children, which ensures the comprehensive well-being of childhood and its ability to also promote and secure face-to-face assistance at school, especially at early ages, since it offers learning and socialization opportunities, which today the virtual world is far from being able to provide.

Finally, this successful example of a mutual support network between children in early childhood education, families, and the school could be considered as a resource or a suggestion to be replicated in other situations of confinement or limitation of face-to-face school attendance, particularly due to the current time full of uncertainties that demand fast and positive adaptations to face future challenges. However, this replication is not exempt from the necessary contextualization that any replication of experiences implies, considering the particularities and limitations of each context (physical, social, economic, etc.). Besides, as future lines of research, it would be interesting to continue exploring and studying educational and social experiences in which the protagonists are early childhood pupils and their families, in order to address in imaginative and innovative ways the needs and challenges of the post-pandemic crisis.

Author Contributions: Conceptualization, A.B.C.-H. and R.A.-B.; methodology, A.B.C.-H.; formal analysis A.B.C.-H. and R.A.-B.; data curation, R.A.-B.; writing-original draft preparation, A.B.C.-H.; writing-review and editing, R.A.-B.; visualization, A.B.C.-H. and R.A.-B.; supervision, A.B.C.-H. All authors have read and agreed to the published version of the manuscript.

Funding: This research received no external funding.

Institutional Review Board Statement: Not applicable.

Informed Consent Statement: Informed consent was obtained from all subjects involved in the study.

Data Availability Statement: Data sharing is not applicable to this article.

Acknowledgments: The authors would like to thank the educational community members of the Cargol Treu Banyes virtual network, especially the children for the lessons they have taught us. We would also like to thank Priscila Álvarez-Cueva for her revisions to the text. We would also like to thank the support of the University of Barcelona through the APAO_UB 2021 grant. This article is part of the first phase of the research "ISICORO: Socially innovative initiatives during the coronavirus pandemic", aimed at identifying and analysing gather solidarity initiatives, socially innovative experiences and institutional support as a response to the social needs derived of the Covid19 Pandemic, within the framework of the CRIT (Creativity, Innovation and Urban Transformation) research group at the University of Barcelona. It is also linked to the doctoral thesis "Validació del progreama 'Toca fusta' el benestar mitjanant la fusta" of the PhD programme in Education and Society of the University of Barcelona. 
Conflicts of Interest: The authors declare no conflict of interest.

\section{References}

1. WHO Director-General's Opening Remarks at the Media Briefing on COVID-19-11 March 2020. Available online: https: / / bit.ly/3laK2SO (accessed on 13 March 2021).

2. United Nations. Transforming Our World: The 2030 Agenda for Sustainable Development. In A New Era in Global Health. Nursing and the United Nations 2030 Agenda for Sustainable Development; Rosa, W., Ed.; Springer Publishing Company: New York, NY, USA, 2017; pp. 529-567. [CrossRef]

3. Thorell, T.L.B.; Skoglund, C.; de la Peña, A.G.; Baeyens, D.; Fuermaier, A.B.M.; Groom, M.J.; Mammarella, I.C.; van der Oord, S.; van den Hoofdakker, B.J.; Luman, M.; et al. Parental Experiences of Homeschooling during the COVID-19 Pandemic: Differences Between Seven European Countries and Between Children with and Without Mental Health Conditions. Eur. Child Adolesc. Psychiatry 2021. [CrossRef]

4. UNESCO. COVID-19 Response-Remote Learning Strategy. Remote Learning Strategy as a Key Element in Ensuring Continued Learning United Nations Educational Scientific and Cultural Organization: Paris, France, 2020; Available online: https://bit.ly/3eyv2wH (accessed on 23 March 2021).

5. Cifuentes, J. Consecuencias en los Niños del Cierre de Escuelas por Covid-19: El Papel del Gobierno, Profesores y Padres. Rev. Int. Educ. Justicia Soc. 2020, 9, 1-12.

6. Gupta, S.; Jawanda, M.K. The Impacts of COVID-19 on Children. Acta Paediatr. 2020, 109, 2181-2183. [CrossRef]

7. Van Lancker, W.; Parolin, Z. COVID-19, School Closures, and Child Poverty: A Social Crisis in the Making. Lancet Public Health 2020, 5, e243-e244. [CrossRef]

8. Rogers, H.; Sabarwal, S. The COVID-19 Pandemic: Shocks to Education and Policy Responses; World Bank: Washington, DC, USA, 2020.

9. United Nations. UN Chief Outlines "Bold Steps" for Education in the Face of COVID-19 Disruption. UN News. 4 August 2020. Available online: https: / / bit.ly/3pDyWa0 (accessed on 23 March 2021).

10. Valero, E.; Martín, U.; Domínguez, A. Covid-19 y Salud Infantil: El Confinamiento y su Impacto Según Profesionales de Infancia. Rev. Esp. Salud Publica 2020, 94, e1-e7.

11. Real Decreto 463/2020, de 14 de Marzo, Por el que se Declara el Estado de Alarma la Gestión de la Situación de Crisis Sanitaria Ocasionada por el COVID-19. Bol. Estado 2020,67, 25390-25400. Available online: https://www.boe.es/eli/es/rd/2020/03/14/4 63/con (accessed on 23 March 2021).

12. Cohen, J.; Kupferschmidt, K. Countries Test Tactics in “War" against COVID-19. Science 2020, 367, 1287-1288. [CrossRef] [PubMed]

13. Mallapaty, S. How Do Children Spread the Coronavirus? The Science Still Isn't Clear. Nature 2020, 581, 127-128. [CrossRef] [PubMed]

14. Viner, R.M.; Russell, S.J.; Croker, H.; Packer, J.; Ward, J.; Stansfield, C.; Mytton, O.; Bonell, C.; Booy, R. School Closure and Management Practices during Coronavirus Outbreaks Including COVID-19: A Rapid Systematic Review. Lancet Child Adolesc. Health 2020, 2019, 1-8. [CrossRef]

15. Ministerio de Sanidad. Orden SND/370/2020, de 25 de Abril, Sobre las Condiciones en las que Deben Desarrollarse los Desplazamientos por Parte de la Población Infantil Durante la Situación de Crisis Sanitaria Ocasionada por el COVID-19. Bol. Estado 2020, 116, 18987-19106. Available online: https://www.boe.es/eli/es/o/2020/04/25/snd370/con (accessed on 23 March 2021).

16. United Nations. Policy Brief: Education during COVID-19 and Beyond; United Nations: New York, NY, USA, 2020; Available online: https:/ / bit.ly/30Dqkpy (accessed on 23 March 2021).

17. UNICEF. COVID-19: Are Children Able to Continue Learning during School Closures. A Global Analysis of the Potential Reach of Remote Learning Policies Using Data from 100 Countries; United Nations Children's Fund: New York, NY, USA, 2020; Available online: https: / / uni.cf/3vcxpeN (accessed on 23 March 2021).

18. Moreno, J.L.; Lluch, L. Educación y Covid-19: Colaboración de las Familias y Tareas Escolares. Rev. Int. Educ. Justicia Soc. 2020, 9 , $1-17$.

19. Dhawan, S. Online Learning: A Panacea in the Time of COVID-19 Crisis. J. Educ. Technol. Syst. 2020, 49, 5-22. [CrossRef]

20. Schneider, S.L.; Council, M.L. Distance Learning in the Era of COVID-19. Arch. Dermatol. Res. 2020. [CrossRef] [PubMed]

21. Dayal, H.C.; Tiko, L. When are We Going to Have the Real School? A Case Study of Early Childhood Education and Care Teachers' Experiences Surrounding Education during the COVID-19 Pandemic. Australas. J. Early Child. 2020, 45, 336-347. [CrossRef]

22. Aznar, F.J. Secondary Education in Spain amid the COVID-19 Crisis. Int. J. Sociol. Educ. 2020, 53-78. [CrossRef]

23. UNESCO. Distance Learning Strategies in Response to COVID-19 School Closures; United Nations Educational Scientific and Cultural Organization: Paris, France, 2020; Available online: https:/ / bit.ly/3lbsHcz (accessed on 23 March 2021).

24. Muhdi, .; Nurkolis, .; Yuliejantiningsih, Y. The Implementation of Online Learning in Early Childhood Education during the Covid-19 Pandemic. JPUD J. Pendidik. Usia Dini 2020, 14, 247-261. [CrossRef]

25. Garbe, A.; Ogurlu, U.; Logan, N.; Cook, P. Parents' Experiences with Remote Education during COVID-19 School Closures. Am. J. Qual. Res. 2020, 4, 45-65. [CrossRef] 
26. Abuhammad, S. Barriers to Distance Learning during the COVID-19 Outbreak: A Qualitative Review from Parents' Perspective. Heliyon 2020, 6. [CrossRef]

27. Bonal, X.; González, S. The Impact of Lockdown on the Learning Gap: Family and School Divisions in Times of Crisis. Int. Rev. Educ. 2020. [CrossRef]

28. Drane, C.; Vernon, L.; Shea, S.O. The Impact of 'Learning at Home' on the Educational Outcomes of Vulnerable Children in Australia during the COVID-19 Pandemic; Curtin University: Perth, Australia, 2020; Available online: https: / bit.ly/3tMMRwp (accessed on 23 March 2021).

29. Gayatri, M. The Implementation of Early Childhood Education in the Time of Covid-19 Pandemic: A Systematic Review. Humanit. Soc. Sci. Rev. 2020, 8, 46-54. [CrossRef]

30. A helping Hand: Education Responding to the Coronavirus Pandemic. Available online: https://bit.ly/3qH2K5y (accessed on 13 March 2021).

31. Cabrera, L. Efectos del Coronavirus en el Sistema de Enseñanza: Aumenta la Desigualdad de Oportunidades Educativas en España. Rev. Sociol. Educ. 2020, 13, 114-139. [CrossRef]

32. Seusan, L.A.; Maradiegue, R. Educación en Pausa: Una Generación de Niños y Niñas en América Latina y el Caribe Está Perdiendo la Escolarización Debido al COVID-19; United Nations Children's Fund: Ciudad de Panamá, Panamá, 2020; Available online: https:/ / uni.cf/3rJtBQ4 (accessed on 23 March 2021).

33. Dong, C.; Cao, S.; Li, H. Young Children's Online Learning during COVID-19 Pandemic: Chinese Parents' Beliefs and Attitudes. Child. Youth Serv. Rev. 2020, 118. [CrossRef]

34. González, S.; Bonal, X. Primera Infancia en Tiempos de Pandemia: Desigualdades Educativas y Desafíos para el Futuro Inmediato. Aula Infant. 2020, 106, 11-14.

35. Bao, X.; Qu, H.; Zhang, R.; Hogan, T.P. Modeling Reading Ability Gain in Kindergarten Children during COVID-19 School Closures. Int. J. Environ. Res. Public Health 2020, 17, 6371. [CrossRef]

36. Muroga, A.; Zaw, H.T.; Mizunoya, S.; Lin, H.C.; Brossard, M.; Reuge, N. COVID-19: A Reason to Double Down on Investments in Pre-primary Education; United Nations Children's Fund: Firenze, Italy, 2020; Available online: https://bit.ly/3qMDpHO (accessed on 23 March 2021).

37. Su, I.A.; Ceci, S.J. “Zoom Developmentalists": Home-Based Videoconferencing Developmental Research during COVID-19. PsyArXiv 2021. [CrossRef]

38. Wiederhold, B.K. Connecting through Technology during the Coronavirus Disease 2019 Pandemic: Avoiding "Zoom Fatigue". Cyberpsychol. Behav. Soc. Netw. 2020, 23, 437-438. [CrossRef] [PubMed]

39. Berasategi, N.; Idoiaga, N.; Dosil, M.; Eiguren, A.; Pikaza, M.; Ozamiz, N. Las Voces de los Niños y de las Niñas en Situación de Confinamiento por el COVID-19; Euskal Herriko Unibertsitatea: Bilbo, Spain, 2020.

40. Martínez, M.; Rodríguez, I.; Velásquez, G. Infancia Confinada. ¿Cómo Viven la Situación de Confinamiento Niñas, Niños y Adolescentes; Infancia Confinada: Madrid, Spain, 2020.

41. Lee, J. Mental Health Effects of School Closures during COVID-19. Lancet Child Adolesc. Health 2020, 4, 421. [CrossRef]

42. Imaz, C.; González, F.; Martínez, A.; Arango, C.; Bellido, G.; Payá, B. Salud Mental en la Infancia y la Adolescencia en la Era del COVID-19. In Evidencias y Recomendaciones de las Asociaciones Profesionales de Psiquiatría y Psicología Clínica; Fundación Española de Psiquiatría y Salud Mental: Madrid, Spain, 2020.

43. UNICEF. Salud Mental e Infancia En El Escenario de COVID-19; UNICEF España: Madrid, Spain, 2020.

44. Orgilés, M.; Morales, A.; Delveccio, E.; Mazzeschi, C.; Espada, J.P. Immediate Psychological Effects of the COVID-19 Quarantine in Youth From Italy and Spain. Front. Psychol. 2020, 11, 579038. [CrossRef] [PubMed]

45. Diener, E.; Suh, E.M.; Lucas, R.E.; Smith, H.L. Subjective Well-Being: Three Decades of Progress. Psychol. Bull. 1999, 125, $276-302$. [CrossRef]

46. Schimmack, U. The Science of Subjective Well-Being; Eid, M., Larsen, R.J., Eds.; Guilford Press: New York, NY, USA, 2008; pp. 97-123. [CrossRef]

47. Espinosa, M.A. Garantía Del Derecho a Educación En Etapa de 0-3 Años. Una Inversión Necesaria y Rentable; UNICEF Comité Español: Barcelona, Spain, 2018.

48. Tarabini, A.; Jacovkis, J. Recerca Escoles Confinades, Informe 4: L'Escola des de la Distància; GEPS-UAB: Bellaterra, Spain, 2020; Available online: https:/ / bit.ly/2PT9Y9Z (accessed on 23 March 2021).

49. Schleicher, A. The Impact of COVID-19 on Education: Insights from Education at a Glance; OECD Publishing: Paris, France, 2020.

50. Tarabini, A.; Jacovkis, J. Recerca Escoles Confinades, Informe 5: Els i les Docents com a Agents Politics; GEPS-UAB: Bellaterra, Spain, 2020; Available online: https:/ / bit.ly /3bNQNXL (accessed on 23 March 2021).

51. Ionescu, C.A.; Paschia, L.; Gudanescu Nicolau, N.L.; Stanescu, S.G.; Neacsu Stancescu, V.M.; Coman, M.D.; Uzlau, M.C. Sustainability Analysis of the E-Learning Education System during Pandemic Period-Covid-19 in Romania. Sustainability 2020, 12, 9030. [CrossRef]

52. Tarabini, A.; Jacovkis, J. Recerca Escoles Confinades, Informe 3: Fer de Docent en un Context Inèdit; GEPS-UAB: Bellaterra, Spain, 2020; Available online: https:/ / bit.ly/3tnQcSn (accessed on 23 March 2021).

53. Coleman, J.S. Social Capital in the Creation of Human Capital. Am. J. Sociol. 1988, 94, 95-120. [CrossRef]

54. Fukuyama, F. Trust: The Social Virtues and the Creation of Prosperity; Free Press Paperback: New York, NY, USA, 1992.

55. Polanyi, K. The Great Transformation: The Political and Economic Origins of Our Time, 2nd ed.; Beacon Press: Boston, MA, USA, 2001. 
56. Putnam, R.D. Making Democracy Work. Civic Traditions in Modern Italy; Princeton University Press: Princeton, NJ, USA, 1993.

57. Krippendorff, K. Content Analysis. An Introduction to Its Methodology, 2nd ed.; Sage Publications: Thousand Oaks, CA, USA, 2004.

58. Glaser, B.G.; Strauss, A.L. The Discovery of Grounded Theory: Strategies for Qualitative Research; Aldine Transaction: New Brunswick, NJ, USA, 1967.

59. Strauss, A.L.; Corbin, J. Basics of Qualitative Research. Techniques and Procedures for Developing Grounded Theory, 4th ed.; SAGE Publications: New York, NY, USA, 2014.

60. Kelly, J.G.; Azelton, L.S.; Burzette, R.G.; Mock, L.O. Creating Social Settings for Diversity: An Ecological Thesis. In Human Diversity: Perspectives on People in Context; Trickett, E.J., Watts, R.J., Birman, D., Eds.; Jossey-Bass: San Francisco, CA, USA, 1994; pp. 424-451.

61. Kozinets, R.V. The International Encyclopedia of Digital Communication and Society; Mansell, R., Ang, P.H., Eds.; Wiley: New York, NY, USA, 2015; pp. 1-8. [CrossRef]

62. Bengry, A.; Wiles, R.; Nind, M.; Crow, G. A Review of the Academic Impact of Three Methodological Innovations: Netnography, Child-Led Research and Creative Research Methods. Social Sciences; ESRC National Centre for Research Methods: Southampton, UK, 2011.

63. Sánchez, W.C.; Ortiz, P.A. Netnografía, Un Modelo Etnográfico en la Era Digital. Espacios 2017, 38, 1-14.

64. García, E.; Herrero, J.; Musitu, G. Evaluación de Recursos y Estresores Psicosociales en Comunidad; Síntesis: Madrid, Spain, 2002.

65. Shumaker, S.A.; Brownell, A. Toward a Theory of Social Support: Closing Conceptual Gaps. J. Soc. Issues 1984, 40, 11-36. [CrossRef]

66. Goldschmidt, K. The COVID-19 Pandemic: Technology Use to Support the Wellbeing of Children. J. Pediatr. Nurs. 2020, 53, 88-90. [CrossRef]

67. Bandaura, A. Social Learning Theory; Prentice-Hall: Oxford, UK, 1977.

68. García, M.; Martínez, M.F.; Albar, M.J. Elección de Fuentes de Apoyo Social Entre Inmigrantes'. Psicothema 2002, 14, 369-374.

69. Sarason, I.G.; Levine, H.M.; Basham, R.B.; Sarason, B.R. Assessing Social Support: The Social Support Questionnaire. J. Pers. Soc. Psychol. 1983, 44, 127-139. [CrossRef]

70. Álvarez-Cueva, P.; Masanet, M.J.; Cano-Hila, A.B. Las Narraciones de la Cuarentena Durante la Crisis de la COVID-19 a Través de la Música: Emociones y Actividades Compartidas por Stay Homas. Hipertext.net 2020, 21, 67-77. [CrossRef]

71. Cavus, N.; Sani, A.S.; Haruna, Y.; Lawan, A.A. Efficacy of Social Networking Sites for Sustainable Education in the Era of COVID-19: A systematic review. Sustainability 2021, 13, 808. [CrossRef]

72. Cano-Hila, A.B.; Argemí-Baldich, R. Taking Care of Us from the Neighbourhoods in Times of Quarantine. Citizen Solidarity Practices in Vallcarca, Barcelona (Spain). Space Cult. 2020, 23, 237-245. [CrossRef]

73. Tönnies, F. Community E Society: (Gemeinschaft und Gesellschaft), 1st ed.; Routledge: London, UK, 2017. [CrossRef]

74. Santoveña-Casal, S.; Fernández Pérez, M.D. Sustainable Distance Education: Comparison of Digital Pedagogical Models. Sustainability 2020, 12, 9067. [CrossRef]

75. COVID-19: Schools for More than 168 Million Children Globally Have Been Completely Closed for Almost a Full Year, Says UNICEF. Available online: https: / / uni.cf/3cxiUJO (accessed on 13 March 2021). 